\title{
Growth Performance of Muscovy Ducks (Cairina moschata) Fed Palm Kernel Meal Based Diets
}

\section{Ruben Ngouana Tadjong1*, Kana Jean Raphaël2, Yemdji Mane Divine Doriane1, Kamkade Yves², Edie Nounamo Longston Wilfried ${ }^{2}$, Teguia Alexis ${ }^{2}$}

\author{
${ }^{1}$ Institute of Fisheries and Aquatic Science of Yabassi, Aquaculture Department, Laboratory of Aquaculture and Demography of \\ Fisheries Resources, University of Douala, Douala, Cameroon \\ ${ }^{2}$ Faculty of Agronomy and Agricultural Sciences, Department of Animal Science, Laboratory of Animal Nutrition, University of \\ Dschang, Dschang, Cameroon \\ Email: ^ngouanarubens@yahoo.fr
}

How to cite this paper: Tadjong, R.N., Raphaël, K.J., Doriane, Y.M.D., Yves, K., Wilfried, E.N.L. and Alexis, T. (2020) Growth Performance of Muscovy Ducks (Cairina moschata) Fed Palm Kernel Meal Based Diets. Open Journal of Animal Sciences, 10, 346-361.

https://doi.org/10.4236/ojas.2020.103021

Received: March 31, 2020

Accepted: May 17, 2020

Published: May 20, 2020

Copyright $\odot 2020$ by author(s) and Scientific Research Publishing Inc. This work is licensed under the Creative Commons Attribution International License (CC BY 4.0).

http://creativecommons.org/licenses/by/4.0/

\begin{abstract}
From a total of 80 fertile eggs incubated naturally by female ducks, healthy sexed ducklings ( $\mathrm{n}=64,32$ males and 32 females ducklings) were randomly selected and allotted to four dietary treatments with four replicates, in a completely randomized design in order to evaluate the effect of varying levels of palm kernel meal (PKM) on performance of ducklings. The dietary treatments comprised R0-control ration, R50-50\% PKM replacement, R75-75\% PKM replacement and R100-100\% PKM replacement of soyabean meal. The main results revealed that the apparent digestive coefficients of dry matter (81.12\%), organic matter $(83.98 \%)$ and NDF $(81.10 \%)$ were higher with the ration in which $50 \%$ (R50-50\% PKM replacement of soyabean meal) of soybean was replaced by palm kernel meal. The highest feed intake in male was recorded with the ration containing 75\% (R75-75\% PKM replacement of soyabean meal) of palm kernel. This same ration (R75-75\% PKM replacement of soyabean meal) equally induced the highest live weight and weight gain in females. The experimental design and arrangement is a $2 \times 4$ factorial arrangement with two sexes and four levels of PKM. In males, the control ration without palm kernel meal induced the highest live weight and highest cumulative weight gain. The lowest feed conversion ratio $(p<0.05)$ was recorded with the control ration regardless of the sex considered. The lowest cost of feed intake and cost of production of a $\mathrm{kg}$ of body weight were obtained respectively in females and males fed on control ration. With the 50\% (R50-50\% PKM replacement of soyabean meal) substitution of soybean meal, the carcass yield was the highest regardless of the sex. Serum content in
\end{abstract}


ALAT, ASAT, creatinine, total cholesterol and total protein were not significantly $(p>0.05)$ affected by the incorporation of palm kernel meal into the diet. Urea serum content tends to decrease with the increasing level of palm kernel meal in feed. In conclusion, soybean meal can advantageously be replaced by palm kernel meal at the level of 75\% (R75-75\% PKM replacement of soyabean meal) in Muscovy duck feed.

\section{Keywords}

Digestibility, Performance, Muscovy Duck, Palm Kernel Meal, Soybean Meal

\section{Introduction}

The ban of animal meal in monogastric feed in the tropics resulted in the rush for leguminous grains which have amino acids profils close to that of animal meal. Soybean meal, which is the main source of proteins in animals feed, has become more expensive over time due to the high demand at the international scale. Hence the need to look for non-conventional sources of protein for livestock nutrition among local resources with less competition with humans becomes essential. Among these resources is palm kernel meal which is a by-product derived from the extraction of oil from palm kernel almonds. Cameroon is rank 13th in the world among palm oil producing countries, with an estimated production of 230,000 tones/year [1]. In addition to the oil, there is a large amount of palm kernel meal derived from the extraction of oil from palm kernel almonds. This palm kernel is very widely available and relatively less expensive (90 to $100 \mathrm{Fcfa} / \mathrm{kg}$ ) compared to others, for example peanut meal (250 $300 \mathrm{Fcfa} / \mathrm{kg}$ ) which is also abundantly produced in Cameroon. Palm kernel meal has not so far been widely used in monogastric feed because of its high cellulose content (17\% to $23 \%)$ and its gravelly and less appetizing state [2] [3]. However, $79 \%$ digestibility of its dry matter and $57 \%$ of its proteins was reported in growing pigs [4]. Also $42 ; 47$ and 63\% digestibility respectively for crude energy, organic matter and crude proteins of palm kernel meal were reported in growing pigs and 50; 54 and 77\% in sow [5]. Furthermore, [6] reported that palm kernel meal can substitute soybean meal up to $40 \%$ in broiler diet with no negative effect on growth performances when supplement of lysine and methionine is made available.

Ducks are more rustic, require less care, resist to disease better than other poultry and feed easily on leftovers [7]. They feed more on green forage than other poultry and are among the best transformers of plant proteins into animal proteins. This ability to consume forage suggests that ducks can make better use of cellulose-rich by-products like palm kernel than other poultry.

The objective of the present study was to promote the utilization of palm kernel as alternatives to soybean meal in monogastric feed in order to reduce the cost of feed when the soyabean is becoming more and more expensive over time. 


\section{Materials and Methods}

This study was carried out at the Teaching and Research Farm (TRF) of the Faculty of Agronomy and Agricultural Sciences (FAAS) of the University of Dschang (UDs), Cameroon. Dschang is located between $5^{\circ} 25^{\prime}$ North latitude and $10^{\circ} 20^{\prime}$ East longitude, at an average altitude of $1420 \mathrm{~m}$ in the agro-ecological zone of the highlands of Western Cameroon. The climate is equatorial and it is characterized by a short dry season (mid-November to mid-March) and a long rainy season (mid-March to mid-November). The average annual rainfall is 2000 $\mathrm{mm}$, the average temperature is around $20^{\circ} \mathrm{C}$ and the relative humidity is generally higher than $60 \%$.

\subsection{Feedlot Growth Performance}

In this study, 80 fertile eggs incubated naturally by female ducks, healthy sexed ducklings $\mathrm{n}=64$ (32 males and 32 females ducklings) dweighing averagely $49.38 \pm$ $2.12 \mathrm{~g}$ at hatching were used. They were produced by natural incubation by female's ducks at the research farm. From hatching, the ducklings were divided into 4 groups of 16 ducklings each. At the 5th week, the ducklings were identified by numbered rings on their legs and the males were raised separately from the females till 12 weeks. The ducklings were housed in a building subdivided into two compartments (one was covered and the other was exposed in the sun). The ducklings were brooded under 100 Watts bulbs as heaters for the first 5 weeks. The litter was made by white wood shavings. From the 5th week, the ducks were raised on a paved floor without litter. No prophylactic program was followed. Nevertheless, an deparasitant (LEVAMIN 200WSP) was administered as a preventive measure in drinking water at the 5th week for 3 consecutive days. At the starter (1 to 8 weeks) and the finisher (9 to 12 weeks) phases, a control ration containing soybean meal as the main source of protein were formulated (R0-control). Three other rations were obtained from this basal ration by substituting 50\% (R50-50\% PKM replacement of soyabean meal), 75\% (R75-75\% PKM replacement of soyabean meal) and 100 (R100-100\% PKM replacement of soyabean meal) of soybean meal with palm kernel meal at the starter phase (Table 1) and at the finisher phase (Table 2).

The experimental design and arrangement is a $2 \times 4$ factorial arrangement with two sexes and four levels of PKM four replicates, in a completely randomized design (sex and inclusion level of palm kernel). Feed and water were given ad libitum throughout the trial period.

Feed previously weighed using an electronic balance of precision $1 \mathrm{~g}$ and maximum capacity $7 \mathrm{~kg}$ were distributed daily to the animals. At the end of each week, the leftovers were collected and weighed. Feed intake was calculated by doing the difference between the total quantity of feed served and the leftovers. The ducklings were weighed initially at hatching and weekly thereafter. Weekly weight gain was achieved by calculating the difference between two consecutive weekly live weights. At the age of 84 days, eight ducks per treatment group 
Table 1. Composition (g/100g) of experimental rations fed to Muscovy ducklings at starter phase.

\begin{tabular}{|c|c|c|c|c|}
\hline \multirow{2}{*}{ Ingredients $(\mathrm{kg})$} & \multicolumn{4}{|c|}{ Rations } \\
\hline & R0 & R50 & R75 & R100 \\
\hline Maize & 50.00 & 60.00 & 60.00 & 62.00 \\
\hline Wheat bran & 23.30 & 9.15 & 5.40 & 1.40 \\
\hline Cotton seed meal & 2.51 & 1.00 & 4.50 & 6.25 \\
\hline Soybean meal & 16.00 & 8.00 & 4.00 & 0.00 \\
\hline Palm kernel meal & 0.00 & 8.00 & 12.00 & 16.00 \\
\hline Fish meal & 2.00 & 4.75 & 5.00 & 2.50 \\
\hline Blood meal & 0.00 & 3.50 & 3.10 & 5.75 \\
\hline Oeister shell & 1.00 & 0.50 & 1.00 & 1.00 \\
\hline premix 5\%* & 5.00 & 5.00 & 5.00 & 5.00 \\
\hline Salt & 0.19 & 0.10 & 0.00 & 0.10 \\
\hline TOTAL & 100.00 & 100.00 & 100.00 & 100.00 \\
\hline \multicolumn{5}{|c|}{ Calculated chemical composition } \\
\hline Metabolisable Energy (kcal/kg) & 20.18 & 20.29 & 19.76 & 19.70 \\
\hline Crude protein (\%) & 2920.97 & 2935.84 & 2860.59 & 2838.90 \\
\hline Energy/Protein & 144.76 & 144.71 & 144.74 & 144.08 \\
\hline Calcium (\%) & 0.98 & 0.96 & 1.18 & 1.02 \\
\hline Phosphorus (\%) & 0.52 & 0.52 & 0.52 & 0.42 \\
\hline Calcium/phosphorus & 1.88 & 1.86 & 2.26 & 2.43 \\
\hline Sodium (\%) & 0.17 & 0.18 & 0.16 & 0.19 \\
\hline Methionine (\%) & 0.41 & 0.44 & 0.43 & 0.40 \\
\hline Lysine (\%) & 1.13 & 1.24 & 1.15 & 1.13 \\
\hline Crude fiber (\%) & 3.70 & 5.22 & 6.16 & 6.73 \\
\hline Fat $(\%)$ & 3.25 & 3.18 & 3.07 & 3.01 \\
\hline
\end{tabular}

${ }^{*}$ Premix 5\%; Metabolizable energy $=2078 \mathrm{Kcal} / \mathrm{Kg}$; Crude protein $=40 \%$; Lysine $=3.3 \%$; Methionine $=$ 2.40; Calcium $=8 \%$; Phosphorus $=2.05 \%$.

(four males and four females) were fasted for 24-hours, then weighed, sacrificed, scalded, plucked and eviscerated [8]. Carcass yields and the relative weight of each organ (gizzard, liver, heart) were recorded at 84 days. The density of the intestine was calculated by dividing the intestine weight/ intestine length.

\subsection{Biochemical Parameters}

During ducks sacrifice for carcass evaluation at 84 days, the blood of each bird was collected in a test tube without anticoagulant and centrifuged at 3000 turns/minute for 15 minutes, then the serum was collected and used for the quantification of creatinine, ALAT and ASAT using the kinetic colorimetric method, the analysis of total proteins and albumin were done by the colorimetric method of Biuret and bromocresol green respectively according to the description of the Chronolab commercial kits. 
Table 2. Composition (g/100 g) of experimental rations fed to Muscovy ducks at finisher phase.

\begin{tabular}{|c|c|c|c|c|}
\hline \multirow{2}{*}{ Ingrédients (kg) } & \multicolumn{4}{|c|}{ Rations } \\
\hline & R0 & R50 & R75 & $\mathrm{R} 100$ \\
\hline Maize & 65.00 & 69.00 & 65.00 & 65.00 \\
\hline Wheat bran & 9.55 & 0.35 & 4.45 & 3.18 \\
\hline Cotton seed meal & 1.00 & 4.00 & 2.00 & 1.75 \\
\hline Soybean meal & 16.00 & 8.00 & 4.00 & 0.00 \\
\hline Palm kernel meal & 0.00 & 8.00 & 12.00 & 16.00 \\
\hline Fish meal & 1.25 & 1.00 & 5.00 & 5.00 \\
\hline Blood meal & 0.00 & 2.40 & 1.50 & 3.00 \\
\hline Bone meal & 1.00 & 1.00 & 0.50 & 0.50 \\
\hline Oeister shell & 1.00 & 1.00 & 0.50 & 0.50 \\
\hline premix 5\%* & 5.00 & 5.00 & 5.00 & 5.00 \\
\hline Salt & 0.20 & 0.10 & 0.03 & 0.03 \\
\hline Methionine & 0.00 & 0.05 & 0.01 & 0.02 \\
\hline Lysine & 0.00 & 0.10 & 0.01 & 0.02 \\
\hline TOTAL & 100.00 & 100.00 & 100.00 & 100.00 \\
\hline \multicolumn{5}{|c|}{ Calculated chemical composition } \\
\hline Metabolisable Energy (kcal/kg) & 18.24 & 17.90 & 17.67 & 17.47 \\
\hline Crude protein (\%) & 2984 & 2921.47 & 2884.47 & 2851.14 \\
\hline Energy/protein & 163.68 & 163.24 & 163.22 & 163.23 \\
\hline Calcium (\%) & 1.17 & 1.17 & 1.10 & 1.11 \\
\hline Phosphorus (\%) & 0.51 & 0.46 & 0.56 & 0.57 \\
\hline Calcium/phosphorus & 2.30 & 2.52 & 1.95 & 1.96 \\
\hline Sodium (\%) & 0.18 & 0.16 & 0.17 & 0.17 \\
\hline Methionine (\%) & 0.38 & 0.42 & 0.42 & 0.42 \\
\hline Lysine (\%) & 1.00 & 1.07 & 1.00 & 1.01 \\
\hline Crude cellulose (\%) & 4.23 & 5.74 & 6.10 & 6.53 \\
\hline Fat (\%) & 3.18 & 3.05 & 3.18 & 3.20 \\
\hline
\end{tabular}

${ }^{*}$ Premix 5\%; Metabolisable energy $=2078 \mathrm{Kcal} / \mathrm{Kg}$; Crude protein $=40 \%$; Lysine $=3.3 \%$; Methionine $=$ 2.40; Calcium $=8 \%$; Phosphorus $=2.05 \%$.

\subsection{Nutrient Digestibility}

At 90 days, twelve ducks of average weight $2687.33 \pm 270.08 \mathrm{~g}$ were individually fed in cages. After 3 days of adaptation, data were collected on 3 successive days. Each cage was equipped with a feeder and water trough. Feed was weighed and served each morning to the animals, the leftovers were collected and weighed the next morning. The faeces produced was collected every morning during the 3 days of the trial. Collected faeces was dried to constant weight in an oven at $60^{\circ} \mathrm{C}$, then crushed and mixed per treatment group. A representative sample per treatment was taken for protein, organic matter, ash and dry matter analysis according to the procedure described by AOAC [9]. Crude fiber content of feed 
and faeces was determined by the method described by Kurscher modified by Sheerer [9]. The Van soest et al. [10] method was used for the determination of Neutral Detergent Fiber (NDF). The coefficients of apparent digestibility of different nutrients were calculated as follow:

$$
\mathrm{ADC}=\frac{\text { Intake }- \text { excreted }}{\text { intake }} \times 100
$$

Data on feed intake, live body weight, feed conversion ratio, carcass characteristics and serum biochemical parameters were subjected to the analysis of variance. Duncan's test was used to separate means when there were significant differences between treatments at the 5\% level. The statistical software used for the analysis was SPSS 20.0 (Statistical Package for Social Sciences).

\section{Results and Discussion}

Table 3 summarizes the effect of the incorporation level of palm kernel meal on feed intake and the digestibility of dry matter (DM), organic matter (OM), nitrogen, crude fiber (CF) and Neutral Detergent Fiber (NDF) of Muscovy Ducks. Compared to the control group, the DM intake increases with the palm kernel meal, regardless of its level in feed. The apparent digestive coefficients (ADC) of $\mathrm{DM}$ and $\mathrm{OM}$ has the same logic but with a saw tooth evolution. This result contradicted previous findings which revealed a decrease in the digestibility [11] of dry matter with the incorporation of $15 \%$ to $35 \%$ palm kernel meal in Muscovy

Table 3. Variation of the digestibility of feed components with respect to the increasing level of palm kernel meal in the ration of Muscovy ducks.

\begin{tabular}{lcccc}
\hline \multirow{2}{*}{ Feed components } & \multicolumn{4}{c}{ Incorporation level of palm kernel meal (\%) } \\
\cline { 2 - 5 } & $\mathbf{0}$ & $\mathbf{5 0}$ & $\mathbf{7 5}$ & 100 \\
\hline Dry matter intake (g) & 362.27 & 419.84 & 375.26 & 424.81 \\
Faeces (g) & 87.06 & 79.28 & 91.30 & 97.45 \\
ADC dry matter (\%) & 75.97 & 81.12 & 75.67 & 77.06 \\
Organic matter intake (g) & 324.29 & 377.56 & 325.35 & 404.36 \\
Faeces organic matter (g) & 62.24 & 60.75 & 66.93 & 70.83 \\
ADC organic matter (\%) & 80.81 & 83.91 & 79.43 & 82.48 \\
Nitrogen intake (g) & 65.85 & 74.84 & 62.61 & 59.66 \\
Excreted nitrogen (g) & 05.18 & 05.72 & 02.81 & 05.15 \\
ADC nitrogen (\%) & 92.13 & 92.35 & 95.50 & 90.63 \\
Crude fiber intake (g) & 20.98 & 29.61 & 27.01 & 27.39 \\
Excreted crude fiber (g) & 15.18 & 15.72 & 12.81 & 15.59 \\
ADC crude fiber (\%) & 27.63 & 46.91 & 52.56 & 43.08 \\
NDF intake (g) & 216.26 & 250.32 & 168.10 & 225.42 \\
Excreted NDF (g) & 46.39 & 47.31 & 50.81 & 58.19 \\
ADC NDF (\%) & 78.55 & 81.10 & 69.77 & 74.18 \\
\hline ADC Appan & & & \\
\hline
\end{tabular}

$\mathrm{ADC}=$ Apparent Digestive Coefficient, $\mathrm{NDF}=$ Neutral Detergent Fiber . 
duck ration. The discrepancies observed with the results of the latter could be due to the type of meal used. There is great variability in the digestibility of palm kernel meal depending on the variety and the origin [6] [12]. Also, the fact that the previous authors incorporated only $35 \%$ of this meal in the ration while in the present trial between $50 \%$ and $100 \%$ palm kernel meal was used may be a significant factor of variation. Compared to the control group, nitrogen intake is higher with $50 \%$ palm kernel meal in feed. Above 50\%, the nitrogen intake decreases linearly with the increasing level of this by-product in feed. The nitrogen $\mathrm{ADC}$ is almost with the control ration without palm kernel meal and the ration containing 50\% palm kernel meal. Above 50\%, this parameter increases with $75 \%$ before decreasing with $100 \%$ of soybean meal replaced by palm kernel meal in feed. This result is not in accordance with the results obtained [6] [13] [14] and in broiler chickens. Indeed, previous authors recorded a decrease in the digestibility of nitrogen with the incorporation of palm kernel meal whatever the level in the ration. The difference with these results could be linked to the animal specie used. This suggests that duck values feed rich in cellulose better than broiler chickens. The drop in nitrogen digestibility beyond $75 \%$ substitution could be explained by the fact that the cellulose level in the ration is very high to the point where the endogenous fibrolytic enzymes of duck are no longer able to break the bonds of the cell walls of palm kernel meal to release nitrogen [6]. Crude fiber intake and digestibility increased with the incorporation of palm kernel meal in the ration. This result corroborates the previous findings [11] which revealed an increase in cellulose digestibility with increasing levels of palm kernel meal in Muscovy duck ration. Unlike nitrogen digestibility, NDF digestibility is evolving in a saw tooth manner with increasing palm kernel meal level in feed. The highest NDF digestibility was achieved with $50 \%$ of this by-product in the ration. Above $50 \%$ of palm kernel meal in feed, NDF digestibility is low compared to the control ration. The digestibility of crude fiber increases with the increasing level of palm kernel meal up to $75 \%$ in feed. However, whatever the level of palm kernel in feed, the digestibility of crude fiber is higher compared to the control ration. This result contradicted the previous findings [6] which reported an increase in NDF digestibility from $12 \%$ to $13 \%$ with the addition of fibrolytic enzymes in the ration of broilers containing $40 \%$ palm kernel meal. These authors explained the improvement in NDF digestibility by the reducing viscosity of rations in the digestive tract and the degradation of plant walls by the enzyme.

In males, the highest feed intake ( $\mathrm{p}<0.05$ ) was recorded with $75 \%$ palm kernel meal as a substitute to soybean compared to rations with $50 \%$ and $100 \%$ substitution. Meanwhile, in females, feed intake increased linearly with the increasing level of this by-product in the ration. Thus, females fed on the ration in which $100 \%$ soybean was substituted by palm kernel meal recorded the highest feed intake ( $\mathrm{p}<0.05)$ compared to the rest of the treatment groups (Table 4). This result corroborates the increase in feed intake with $40 \%$ of this meal replacing 
Table 4. Variation in growth parameters of Muscovy duck as a function of sex and the incorporation level of palm kernel meal in the rations.

\begin{tabular}{|c|c|c|c|c|c|c|}
\hline \multirow{2}{*}{ Parameters } & \multirow{2}{*}{ Sex } & \multicolumn{4}{|c|}{ Rations } & \multirow{2}{*}{$\mathbf{P}$} \\
\hline & & R0 & R50 & R75 & R100 & \\
\hline \multirow{3}{*}{$\mathrm{FI}(\mathrm{g})$} & 0 & $\begin{array}{c}10,651.69 \pm \\
126.84^{\mathrm{b}}\end{array}$ & $\begin{array}{c}10,291.98 \pm \\
116.80^{c}\end{array}$ & $\begin{array}{c}10,875.34 \pm \\
180.25^{\mathrm{a}}\end{array}$ & $\begin{array}{c}8909.29 \pm \\
100.53^{\mathrm{d}}\end{array}$ & 0.000 \\
\hline & q & $\begin{array}{c}7232.70 \pm \\
74.78^{\mathrm{c}}\end{array}$ & $\begin{array}{c}7327.08 \pm \\
111.22^{c}\end{array}$ & $\begin{array}{c}7883.38 \pm \\
86.11^{\mathrm{b}}\end{array}$ & $\begin{array}{c}8673.12 \pm \\
144.23^{\mathrm{a}}\end{array}$ & 0.000 \\
\hline & ôto & $\begin{array}{c}8562.31 \pm \\
100.81^{\mathrm{b}}\end{array}$ & $\begin{array}{c}8809.53 \pm \\
0.00^{\mathrm{b}}\end{array}$ & $\begin{array}{c}9379.36 \pm \\
133.18^{\mathrm{a}}\end{array}$ & $\begin{array}{c}8791.20 \pm \\
122.38^{\mathrm{b}}\end{array}$ & 0.002 \\
\hline \multirow{3}{*}{ LW (g) } & $\hat{0}$ & $\begin{array}{c}2957.67 \pm \\
173.30^{\mathrm{a}}\end{array}$ & $\begin{array}{c}2459.38 \pm \\
117.28^{\mathrm{bc}}\end{array}$ & $\begin{array}{c}2566.75 \pm \\
192.69^{\mathrm{b}}\end{array}$ & $\begin{array}{c}2318.25 \pm \\
178.73^{\mathrm{c}}\end{array}$ & 0.000 \\
\hline & q & $\begin{array}{c}1571.33 \pm \\
60.45^{\mathrm{a}}\end{array}$ & $\begin{array}{c}1416.50 \pm \\
73.88^{\mathrm{b}}\end{array}$ & $\begin{array}{c}1579.80 \pm \\
83.43^{\mathrm{a}}\end{array}$ & $\begin{array}{c}1444.00 \pm \\
62.26^{\mathrm{b}}\end{array}$ & 0.000 \\
\hline & oro & $\begin{array}{c}2096.94 \pm \\
314.65^{\mathrm{a}}\end{array}$ & $\begin{array}{c}1937.94 \pm \\
66.87^{\mathrm{ab}}\end{array}$ & $\begin{array}{c}2101.31 \pm \\
104.87^{\mathrm{a}}\end{array}$ & $\begin{array}{c}1881.13 \pm \\
81.01^{\mathrm{b}}\end{array}$ & 0.040 \\
\hline \multirow{3}{*}{ CAG (g) } & 0 & $\begin{array}{c}2907.37 \pm \\
173.30^{\mathrm{a}}\end{array}$ & $\begin{array}{c}2410.50 \pm \\
117.28^{\mathrm{bc}}\end{array}$ & $\begin{array}{c}2514.68 \pm \\
192.69^{\mathrm{b}}\end{array}$ & $\begin{array}{c}2272.25 \pm \\
178.73^{c}\end{array}$ & 0.000 \\
\hline & q & $\begin{array}{c}1521.03 \pm \\
60.45^{\mathrm{a}}\end{array}$ & $\begin{array}{c}1367.63 \pm \\
73.88^{\mathrm{b}}\end{array}$ & $\begin{array}{c}1527.73 \pm \\
83.43^{\mathrm{a}}\end{array}$ & $\begin{array}{c}1398.00 \pm \\
62.26^{\mathrm{b}}\end{array}$ & 0.000 \\
\hline & ơ $P$ & $\begin{array}{c}2046.64 \pm \\
314.65^{\mathrm{a}}\end{array}$ & $\begin{array}{c}1889.08 \pm \\
66.87^{\mathrm{ab}}\end{array}$ & $\begin{array}{c}2049.24 \pm \\
104.87^{\mathrm{a}}\end{array}$ & $\begin{array}{c}1835.12 \pm \\
81.01^{\mathrm{b}}\end{array}$ & 0.045 \\
\hline \multirow{3}{*}{ FCR } & $\hat{\sigma}$ & $3.67 \pm 0.22^{\mathrm{b}}$ & $4.28 \pm 0.22^{\mathrm{a}}$ & $4.35 \pm 0.34^{\mathrm{a}}$ & $3.94 \pm 0.31^{\mathrm{b}}$ & 0.000 \\
\hline & q & $4.76 \pm 0.19^{c}$ & $5.37 \pm 0.30^{\mathrm{b}}$ & $5.17 \pm 0.28^{\mathrm{b}}$ & $6.21 \pm 0.27^{\mathrm{a}}$ & 0.006 \\
\hline & ơo & $4.36 \pm 0.28^{c}$ & $4.82 \pm 0.18^{\mathrm{b}}$ & $4.69 \pm 0.21^{\mathrm{b}}$ & $5.08 \pm 0.15^{\mathrm{a}}$ & 0.000 \\
\hline
\end{tabular}

a, b, c: the means with the same letters on the same line are not significantly different; LW: Live Weight; CAG: Cumulative Average Gain; FI: Feed intake; FCR: Feed Conversion Ratio; p: Probability, $\widehat{\delta}=$ male; 우 $=$ female.

soybean meal in duck ration in previous study [15]. Likewise, an improvement in feed intake with the incorporation of $15 \%$ to $35 \%$ of this meal in the ration of Muscovy ducks was also reported [11]. This increase in feed intake might be due to the presence of palm kernel oil residues in the ration. It is well established that the presence of oil in poultry ration improves feed palatability and promotes feed intake [15]. Another explanation to this result could be the acceleration of the intestinal transit time due to the high fiber contents in the rations containing palm kernel meal [11] [16].

The regression of the inclusion level of palm kernel meal on feed intake is illustrated in Figure 1. It appears that $52 \%\left(\mathrm{R}^{2}=0.67\right)$ of the variation in feed intake is explained by the increase in the incorporation level of palm kernel meal in the ration. The parabolic profile of the curve indicates an increase in feed intake of males with respect to the incorporation level of palm kernel meal in the ration up to a peak of $75 \%$ before decreasing with the maximum level of this by-product in feed. 


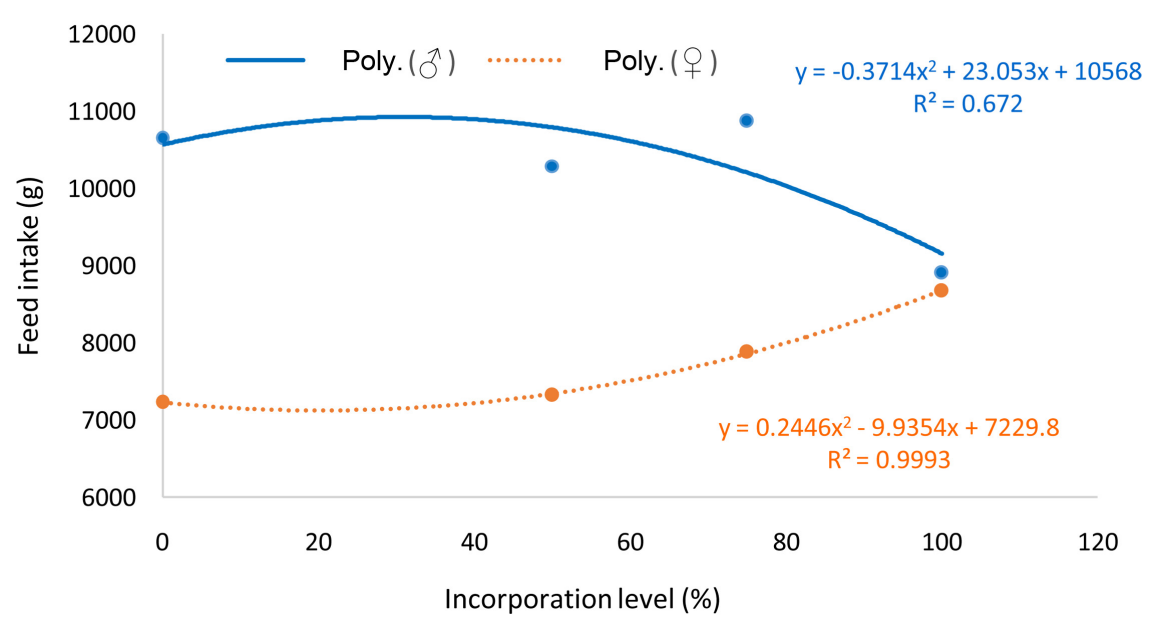

Figure 1. Regression of feed intake on the incorporation level of palm kernel meal in the ration of Muscovy ducks. $\hat{\sigma}=$ male; $q=$ female.

Whatever the sex, the incorporation of palm kernel meal in the ration significantly $(\mathrm{p}<0.05)$ decreased the live weigth with increasing level of this meal in the ration. In males, the weight of animals fed on control ration without palm kernel was significantly $(\mathrm{p}<0.05)$ higher than that of all the groups fed on palm kernel. In females, the highest live weights $(\mathrm{p}<0.05)$ were recorded in animals fed on the ration containing $75 \%$ palm kernel meal as a substitute to soybean and the control ration compared to those receiving rations containing 50 and $100 \%$ palm kernel meal which recorded the lowest weights. Likewise, no significant difference was observed between the live weight of broilers receiving a ration containing 7\% palm kernel meal and those fed on the ration without palm kernel [17]. Meanwhile, the substitution of $100 \%$ soybean meal by palm kernel meal resulted to the lowest live weight compared to the other levels. This result could be explained by a low digestibility of the components of this ration due to high fiber content. This drop in weight could also be explained by the fact that at $75 \%$, the incorporation level is higher and endogenous enzymes can no longer digest the excess fiber provided by this by-product in the ration as previously mentioned [18]. The decrease in males ducks weight with the increasing level of this by-product is illustrated by the regression curve of Figure 2. Indeed, the downward trend of the curve reflects a decrease in live weight of males with the increasing level of palm kernel meal in the ration. However, the relationship between the two parameters is very weak $(\mathrm{p}<0.05)$ as indicated by the low regression coefficient obtained $\left(\mathrm{R}^{2}=0.1974\right)$ in female suggesting that to the increasing level of this meal, did not negatively affect the live weigth in female duck.

Feed conversion ratio significantly increased with the increasing incorporation level of palm kernel meal in the ration (Table 4). Thus, the lowest $(\mathrm{p}<0.05)$ feed conversion ratio was recorded with the control ration compared to the other rations irrespective to the inclusion level of palm kernel. In females, the highest feed conversion ratio was recorded with rations having the highest level palm 


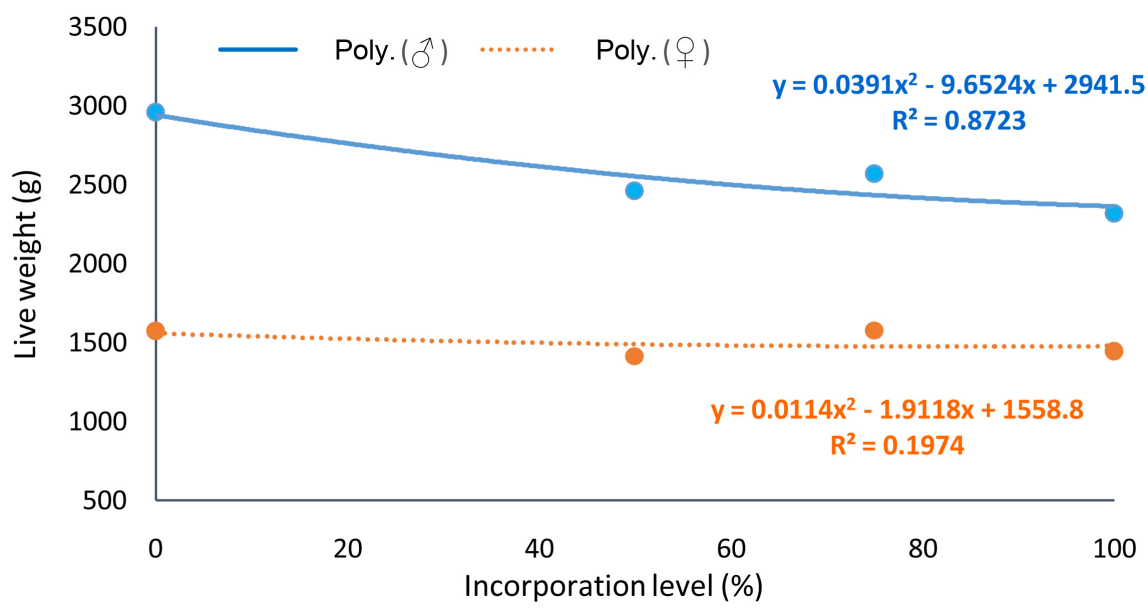

Figure 2. Regression of live weight with respect to the incorporation level of palm kernel meal in the ration of Muscovy ducks. $\hat{\delta}=$ male; $q=$ female.

kernel. Whereas in males, the highest $(\mathrm{p}<0.05)$ feed conversion ratio were recorded with $50 \%$ and $75 \%$ of palm kernel compared to the control group and the group receiving feed with $100 \%$ of this meal (Figure 3). The present result is similar to the performance recorded in broilers fed on rations containing different levels of palm kernel meal [19] [20]. In a previous study, the incorporation of $5 \%, 10 \%, 15 \%$ and $20 \%$ palm kernel meal in broilers diet resulted in an increase in feed conversion ratio for $5.8 \%$; $16.5 \% ; 25.6 \%$ and $23.0 \%$ respectively compared to the control [21]. This increase reflects the low digestibility of this by-product by the duck due to its high fiber content [11]. Indeed, it is well established that the best digestive utilization of feed in poultry is inversely proportional to its fiber content [22]. The present result contradicted the previous findings which revealed a decrease in feed conversion ratio when $20 \%$ palm kernel meal was incorporated in the ration of broilers [21]. A decrease in feed conversion ratio was also reported when $45 \%$ of palm kernel meal was incorporated in the ration of broilers [23]. The divergence observed between these results is not only linked to the animal species used and the changing incorporation level, but may also linked to the type and variety of palm kernel meal used [19].

Table 5 summarizes the effect of incorporation level of palm kernel meal into the ration on the production cost of Muscovy duck. The inclusion level of palm kernel meal into the ration significantly affected $(\mathrm{P}<0.05)$ the feed intake cost and production of $\mathrm{kg}$ of bodyweight regardless of the sex considered. These costs have evolved in a jagged pattern varying from one sex to another. Thus, the highest feed intake cost $(\mathrm{P}<0.05)$ was recorded in males fed on control ration. In females, the highest feed intake cost $(\mathrm{P}<0.05)$ was recorded with the ration containing only palm kernel meal (R100) as the main source of plant proteins.

The production cost of a $\mathrm{kg}$ of live weight decreased with the inclusion of more than $50 \%$ palm kernel meal as a substitute to soybean meal in the ration. This result is similar to the previous report which reported a drop in the cost of production with the increasing inclusion levels of palm kernel in the ration of 


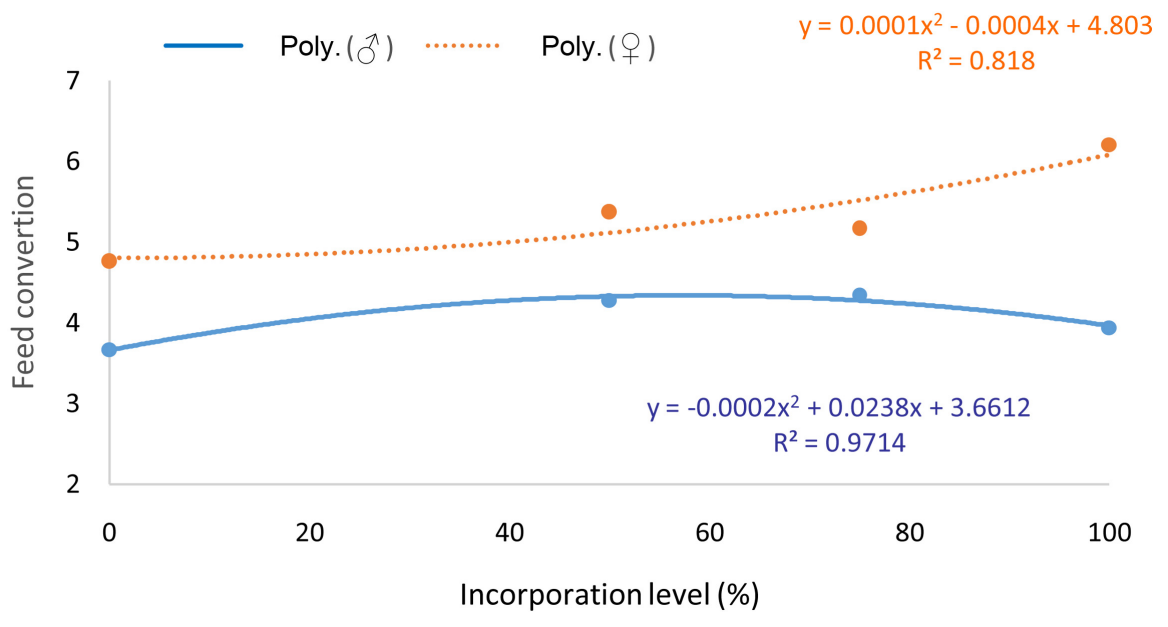

Figure 3. Regression of feed conversion ratio with respect to the incorporation level of palm kernel meal in the ration of Muscovy ducks. $\widehat{\delta}=$ male; $q=$ female.

Table 5. Variation in the cost of production of Muscovy duck as a function of sex and the incorporation level of palm kernel meal into the ration.

\begin{tabular}{|c|c|c|c|c|c|c|}
\hline \multirow{2}{*}{$\begin{array}{l}\text { Economics } \\
\text { Parameters }\end{array}$} & \multirow{2}{*}{ Sex } & \multicolumn{4}{|c|}{ Rations } & \multirow{2}{*}{$\mathbf{P}$} \\
\hline & & Ro & R50 & R75 & $\mathrm{R} 100$ & \\
\hline \multirow{3}{*}{$\begin{array}{l}\text { Feed intake } \\
\text { cost (Fcfa) }\end{array}$} & $\widehat{\sigma}$ & $\begin{array}{c}1798.58 \pm \\
17.22^{\mathrm{a}}\end{array}$ & $\begin{array}{c}1767.02 \pm \\
13.56^{\mathrm{b}}\end{array}$ & $\begin{array}{c}1720.83 \pm \\
08.01^{\mathrm{c}}\end{array}$ & $\begin{array}{c}1411.93 \pm \\
53.18^{\mathrm{d}}\end{array}$ & 0.000 \\
\hline & $q$ & $\begin{array}{c}1052.63 \pm \\
16.25^{\mathrm{d}}\end{array}$ & $\begin{array}{c}1130.97 \pm \\
10.02^{c}\end{array}$ & $\begin{array}{c}1124.33 \pm \\
21.30^{\mathrm{b}}\end{array}$ & $\begin{array}{c}1366.56 \pm \\
22.12^{\mathrm{a}}\end{array}$ & 0.000 \\
\hline & $\delta 9$ & $\begin{array}{c}1342.72 \pm \\
16.74^{\mathrm{ab}}\end{array}$ & $\begin{array}{c}1449.00 \pm \\
11.79^{\mathrm{a}}\end{array}$ & $\begin{array}{c}1422.58 \pm \\
14.70^{\mathrm{b}}\end{array}$ & $\begin{array}{c}1389.24 \pm \\
37.65^{\mathrm{ab}}\end{array}$ & 0.008 \\
\hline \multirow{3}{*}{$\begin{array}{l}\text { Cost of } \\
\text { production } \\
\text { (Fcfa) }\end{array}$} & $\hat{\sigma}$ & $\begin{array}{c}801.74 \pm \\
48.38^{\mathrm{b}}\end{array}$ & $\begin{array}{c}917.94 \pm \\
46.52^{\mathrm{a}}\end{array}$ & $\begin{array}{c}866.81 \pm \\
68.52^{\mathrm{a}}\end{array}$ & $\begin{array}{c}757.26 \pm \\
60.19^{\mathrm{b}}\end{array}$ & 0.000 \\
\hline & q & $\begin{array}{c}1038.94 \pm \\
41.60^{\mathrm{b}}\end{array}$ & $\begin{array}{c}1152.39 \pm \\
64.53^{\mathrm{a}}\end{array}$ & $\begin{array}{c}1031.25 \pm \\
56.45^{\mathrm{b}}\end{array}$ & $\begin{array}{c}1193.42 \pm \\
52.85^{\mathrm{a}}\end{array}$ & 00004 \\
\hline & $\delta 9$ & $\begin{array}{c}951.74 \pm \\
61.48^{\mathrm{b}}\end{array}$ & $\begin{array}{c}1035.17 \pm \\
38.23^{\mathrm{a}}\end{array}$ & $\begin{array}{c}936.17 \pm \\
42.29^{\mathrm{b}}\end{array}$ & $\begin{array}{c}975.34 \pm \\
29.16^{\mathrm{b}}\end{array}$ & 0.001 \\
\hline
\end{tabular}

a, b, c, d: The means with the same letters on the same line are not significantly different $(\mathrm{p}<0.05)$ : Fcfa: franc des colonies Française en Afrique, $\hat{\sigma}=$ male; + $=$ female.

broilers [15]. This drop in production cost is due to the low cost of this ingredient which it is locally available and very abundant in all seasons.

\subsection{Carcass Characteristics}

From Table 6 which summarizes the effect of the incorporation level of palm kernel meal in the ration on the carcass characteristics of duck, it can be seen that the increase in the level of palm kernel meal significantly $(p<0.05)$ affected carcass parameters with the exception of the relative weight of the heart, the liver and the abdominal fat. Regardless of sex, the highest carcass yield $(p<0.05)$ was obtained with $50 \%$ of palm kernel in the diet. In males, the highest carcass ( $\mathrm{p}<$ $0.05)$ yield was recorded with palm kernel free ration and the ration containing 
Table 6. Variation of carcass characteristics with respect to sex and the incorporation level of palm kernel meal in the ration.

\begin{tabular}{|c|c|c|c|c|c|c|}
\hline \multirow{2}{*}{$\begin{array}{c}\text { Carcass } \\
\text { charateristics }\end{array}$} & \multirow{2}{*}{ Sex } & \multicolumn{4}{|c|}{ Rations } & \multirow{2}{*}{$P$} \\
\hline & & Ro & $\mathrm{R} 50$ & R75 & $\mathrm{R} 100$ & \\
\hline \multirow{3}{*}{ carcass } & $\hat{0}$ & $69.33 \pm 2.01^{\mathrm{a}}$ & $70.02 \pm 0.85^{\mathrm{a}}$ & $67.44 \pm 0.77^{\mathrm{b}}$ & $66.09 \pm 0.61^{b}$ & 0.002 \\
\hline & ㅇ & $69.03 \pm 0.70^{\mathrm{ab}}$ & $72.51 \pm 1.90^{\mathrm{a}}$ & $67.61 \pm 1.13^{\mathrm{b}}$ & $67.17 \pm 0.82^{\mathrm{b}}$ & 0.008 \\
\hline & $\hat{o}$ or & $69.18 \pm 1.41^{\mathrm{ab}}$ & $71.26 \pm 4.13^{\mathrm{a}}$ & $67.52 \pm 0.90^{\mathrm{bc}}$ & $66.62 \pm 0.88^{c}$ & 0.002 \\
\hline \multirow{3}{*}{ Head } & $\pi$ & $4.22 \pm 0.31^{\mathrm{ab}}$ & $4.08 \pm 0.08^{\mathrm{b}}$ & $4.58 \pm 0.29^{\mathrm{a}}$ & $4.00 \pm 0.22^{\mathrm{b}}$ & 0.029 \\
\hline & 우 & $4.94 \pm 0.14^{\mathrm{a}}$ & $4.44 \pm 0.45^{\mathrm{b}}$ & $5.25 \pm 0.21^{\mathrm{a}}$ & $4.49 \pm 0.13^{\mathrm{b}}$ & 0.003 \\
\hline & ôto & $4.57 \pm 0.44^{\mathrm{ab}}$ & $4.26 \pm 0.36^{\mathrm{b}}$ & $4.91 \pm 0.43^{\mathrm{a}}$ & $4.24 \pm 0.31^{\mathrm{b}}$ & 0.006 \\
\hline \multirow{3}{*}{ Legs } & $\hat{o}$ & $2.80 \pm 0.13^{\mathrm{b}}$ & $2.74 \pm 0.05^{\mathrm{b}}$ & $3.09 \pm 0.15^{\mathrm{a}}$ & $2.88 \pm 0.23^{\mathrm{ab}}$ & 0.047 \\
\hline & 우 & $2.70 \pm 0.17^{\mathrm{a}}$ & $2.75 \pm 0.45^{\mathrm{a}}$ & $2.52 \pm 0.20^{\mathrm{a}}$ & $2.52 \pm 0.10^{\mathrm{a}}$ & 0.515 \\
\hline & $\hat{o} q$ & $2.75 \pm 0.16^{\mathrm{a}}$ & $2.75 \pm 0.30^{\mathrm{a}}$ & $2.80 \pm 0.35^{\mathrm{a}}$ & $2.70 \pm 0.26^{\mathrm{a}}$ & 0.904 \\
\hline \multirow{3}{*}{ Heart } & $\hat{0}$ & $0.91 \pm 0.05$ & $0.78 \pm 0.04$ & $0.86 \pm 0.09$ & $0.77 \pm 0.07$ & 0.053 \\
\hline & q & $0.86 \pm 0.09$ & $0.89 \pm 0.10$ & $0.97 \pm 0.12$ & $0.85 \pm 0.12$ & 0.468 \\
\hline & $\delta p$ & $0.88 \pm 0.08$ & $0.83 \pm 0.09$ & $0.91 \pm 0.12$ & $0.81 \pm 0.10$ & 0.195 \\
\hline \multirow{3}{*}{ Liver } & $0^{\pi}$ & $1.55 \pm 0.17$ & $1.54 \pm 0.18$ & $1.58 \pm 0.26$ & $1.63 \pm 0.16$ & 0.918 \\
\hline & q & $1.31 \pm 0.21$ & $1.23 \pm 0.20$ & $1.38 \pm 0.06$ & $1.50 \pm 0.10$ & 0.165 \\
\hline & $\hat{o}$ 우 & $1.42 \pm 0.22$ & $1.38 \pm 0.24$ & $1.47 \pm 0.21$ & $1.56 \pm 0.14$ & 0.364 \\
\hline \multirow{3}{*}{ Pancreas } & 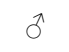 & $0.13 \pm 0.01^{b}$ & $0.09 \pm 0.04^{\mathrm{b}}$ & $0.19 \pm 0.04^{\mathrm{a}}$ & $0.22 \pm 0.03^{\mathrm{a}}$ & 0.000 \\
\hline & 우 & $0.16 \pm 0.03^{\mathrm{a}}$ & $0.19 \pm 0.04^{\mathrm{a}}$ & $0.27 \pm 0.08^{\mathrm{a}}$ & $0.23 \pm 0.06^{\mathrm{a}}$ & 0.111 \\
\hline & do & $0.14 \pm 0.03^{\mathrm{b}}$ & $0.14 \pm 0.06^{\mathrm{b}}$ & $0.23 \pm 0.07^{\mathrm{a}}$ & $0.22 \pm 0.05^{\mathrm{a}}$ & 0.010 \\
\hline \multirow{3}{*}{ Abdominal fat } & 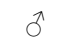 & $0.34 \pm 0.05$ & $0.19 \pm 0.38$ & $0.27 \pm 0.54$ & $0.41 \pm 0.44$ & 0.878 \\
\hline & 우 & $0.21 \pm 0.31$ & $0.03 \pm 0.06$ & $0.00 \pm 0.00$ & $0.10 \pm 0.20$ & 0.431 \\
\hline & ôto & $0.27 \pm 0.22$ & $0.11 \pm 0.27$ & $0.13 \pm 0.38$ & $0.25 \pm 0.36$ & 0.635 \\
\hline
\end{tabular}

$\mathrm{a}, \mathrm{b}, \mathrm{c}$ : The means with the same letter on the same line are not significantly different: $(\mathrm{p}<0.05) p$ : probability, $\hat{o}=$ male; $\stackrel{q}{=}$ female.

$50 \%$ of this by product as substitute of soybean meal. In females, the control ration induced the highest carcass yield. Between $20 \%$ and $30 \%$ of this meal in the ration recent studies [21] and [23] reported a significantly higher carcass yield of broilers compared to the control ration without palm kernel meal. This result contradicted the findings of Bello et al. [15] who reported a non-significant effect on comparable carcass yields with the incorporation of $10 \%$ to $40 \%$ palm kernel meal in broiler ration. The divergence observed between these different works can be due to the nutritional value of this by-product which varies according to the variety of palm and the incorporation level practiced in the different studies.

Table 7 summarizes the effect of incorporation level of palm kernel meal in the ration on the development of duck's digestive organs. The length and density of the intestine were significantly $(\mathrm{p}<0.05)$ affected by the incorporation level of palm kernel meal in the ration only in females. No significant $(p>0.05)$ difference was recorded between treatments for weight, length and density of the 
Table 7. Development of Muscovy duck digestion organs with regard to sex and the incorporation level of palm kernel meal in the ration.

\begin{tabular}{|c|c|c|c|c|c|c|}
\hline \multirow{2}{*}{ Organs } & \multirow{2}{*}{ Sex } & \multicolumn{4}{|c|}{ Rations } & \multirow{2}{*}{$\mathrm{p}$} \\
\hline & & Ro & R50 & R75 & R100 & \\
\hline \multirow{3}{*}{$\begin{array}{l}\text { Intestine } \\
\text { weight (g) }\end{array}$} & 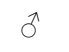 & $78.50 \pm 12.23^{\mathrm{a}}$ & $64.00 \pm 15.42^{\mathrm{a}}$ & $67.75 \pm 7.63^{\mathrm{a}}$ & $80.75 \pm 15.30^{\mathrm{a}}$ & 0.251 \\
\hline & q & $50.50 \pm 4.35^{\mathrm{a}}$ & $28.00 \pm 2.16^{c}$ & $50.00 \pm 5.60^{\mathrm{ab}}$ & $44.25 \pm 1.25^{\mathrm{b}}$ & 0.000 \\
\hline & ôt & $64.50 \pm 17.21^{\mathrm{a}}$ & $46.00 \pm 21.78^{\mathrm{a}}$ & $58.87 \pm 11.33^{\mathrm{a}}$ & $62.50 \pm 21.95^{\mathrm{a}}$ & 0.211 \\
\hline \multirow{3}{*}{$\begin{array}{l}\text { Intestine } \\
\text { length }(\mathrm{cm})\end{array}$} & $\hat{0}$ & $195.50 \pm 4.79^{\mathrm{a}}$ & $171.13 \pm 26.71^{\mathrm{a}}$ & $188.25 \pm 10.90^{\mathrm{a}}$ & $200.50 \pm 24.07^{a}$ & 0.194 \\
\hline & q & $173.25 \pm 23.79^{\mathrm{a}}$ & $132.25 \pm 9.42^{\mathrm{b}}$ & $154.75 \pm 5.05^{\mathrm{ab}}$ & $153.50 \pm 11.50^{\mathrm{ab}}$ & 0.013 \\
\hline & $\delta q$ & $184.37 \pm 19.85^{\mathrm{a}}$ & $151.68 \pm 27.85^{\mathrm{a}}$ & $171.50 \pm 19.56^{\mathrm{a}}$ & $177.00 \pm 30.60^{\mathrm{a}}$ & 0.078 \\
\hline \multirow{3}{*}{$\begin{array}{l}\text { Intestine } \\
\text { density } \\
(\mathrm{g} / \mathrm{cm})\end{array}$} & $\hat{0}$ & $0.40 \pm 0.06^{\mathrm{a}}$ & $0.38 \pm 0.09^{\mathrm{a}}$ & $0.36 \pm 0.02^{\mathrm{a}}$ & $0.40 \pm 0.03^{\mathrm{a}}$ & 0.728 \\
\hline & 우 & $0.29 \pm 0.04^{\mathrm{a}}$ & $0.21 \pm 0.01^{\mathrm{a}}$ & $0.32 \pm 0.02^{\mathrm{a}}$ & $0.29 \pm 0.01^{b}$ & 0.001 \\
\hline & ơ & $0.35 \pm 0.08^{\mathrm{a}}$ & $0.29 \pm 0.11^{\mathrm{a}}$ & $0.34 \pm 0.03^{\mathrm{a}}$ & $0.34 \pm 0.06^{\mathrm{a}}$ & 0.467 \\
\hline \multirow{3}{*}{ Gizzard (g) } & $\hat{\sigma}$ & $2.27 \pm 0.16^{\mathrm{a}}$ & $2.18 \pm 0.13^{\mathrm{a}}$ & $2.42 \pm 0.05^{\mathrm{a}}$ & $2.46 \pm 0.27^{\mathrm{a}}$ & 0.120 \\
\hline & 우 & $2.49 \pm 0.17^{\mathrm{a}}$ & $2.08 \pm 0.33^{b}$ & $2.76 \pm 0.20^{\mathrm{a}}$ & $2.55 \pm 0.14^{\mathrm{a}}$ & 0.008 \\
\hline & $\partial^{\lambda}+q$ & $2.37 \pm 0.20^{\mathrm{a}}$ & $2.12 \pm 0.24^{\mathrm{b}}$ & $2.59 \pm 0.23^{\mathrm{a}}$ & $2.51 \pm 0.20^{\mathrm{a}}$ & 0.001 \\
\hline
\end{tabular}

$a, b, c:$ The means with the same letter on the same line are not significantly different $(p<0.05)$; : probability; $\hat{O}=$ male; + = female.

intestine in males. The incorporation of more than 50\% palm kernel meal in the ration resulted in an increase in the relative weight of the gizzard in females. This result is similar to those recorded in many other studies [23] [24] and [21]. The increase in the relative weight of the gizzard could be related to the high fiber content of this ingredient and its gravelly state which affects the overall state of the ration inducing a more intense mechanical activity in this organ as previously stated some authors [25].

\subsection{Biochemical Parameters}

Serum content in ALAT, ASAT, and creatinine are comparable ( $\mathrm{p}>0.05)$ regardless of the level of palm kernel meal in feed and significantly $(\mathrm{p}<0.05)$ lower than the levels induced by the control ration. The ration containing $75 \%$ palm kernel meal induced the highest serum content in urea of all groups including the control ration. The highest serum protein level was recorded with the control ration compared to all the rations containing palm kernel meal regardless of the level. Triglyceride levels in the blood fluctuate sharply with the increasing level of palm kernel meal in feed. The control ration is comparable to the ration containing $75 \%$ of palm kernel meal and significantly $(\mathrm{p}<0.05)$ higher than the rations containing $50 \%$ and $100 \%$ of this by-product for triglyceride content. The lowest level of triglyceride being recorded with the highest level of palm kernel meal in feed. This result is similar to the result of [26] which reported a drop in triglyceride and cholesterol levels when fiber level was increased in broiler ration. This decrease could be a reflection of the increase in fecal excretion of cholesterol and bile acids involved in the digestion of lipids [27]. 


\section{Implication}

The results presented in this study indicate that up to $75 \%$ soybean meal can be substituted with palm kernel meal especially female duck feed to reduce the cost of production without any negative effect on performance.

\section{Acknowledgements}

The authors acknowledged the facilities provided by the University of Dschang through the Teaching and Research Farm (TRF) of the Faculty of Agronomy and Agricultural Sciences and the Laboratory of Animal Nutrition.

\section{Conflicts of Interest}

The authors declare no conflicts of interest regarding the publication of this paper.

\section{References}

[1] CIFOR Center for International Forestry Research (2012) Le développement du palmier à huile au Cameroun. 3 p. http://www.panda.org/www.ird.fr/www.cifor.org

[2] Gohl, B. (1981) Tropical Feeds. FAO Animal Production and Health Series No. 12. FAO, Rome, 529 p. https://searchworks.stanford.edu/view/1479772

[3] Huart, A. (2004) L'aliment pour volaille est un assemblage d'ingrédients. Centre agronomique et Vétérinaire tropical de Kinshasa, 5 p.

[4] Agunbiade, J.A., Wiseman, J. and Cole, D.J.A. (1999) Energy and Nutrient Use of Palm Kernels, Palm Kernel Meal and Palm Kernel Oil in Diets for Growing Pigs. Animal Feed Science and Technology, 80, 165-181.

https://www.feedipedia.org/node/10415 https://doi.org/10.1016/S0377-8401(99)00070-X

[5] INRA (2002) Institut National de Recherches Agronomiques, Tables de composition et de valeur nutritive des matières premières destinées aux animaux d'élevage (porcs, volailles, bovins, ovins, caprins, lapin, poissons). INRA, Paris, 300 p.

[6] Sundu, B., Kumar, A. and Dingle, J. (2005) Response of Birds Feed Increasing Levels of Palm Kernel Meal Supplemented with Enzymes. Australian Poultry Science Symposium, 17, 227-228. https://www.ncbi.nlm.nih.gov/pmc/articles/PMC4782089

[7] Vander, S.J., Meulen, G. and Den Dikken (2004) L'élevage de canards, Agrodok 33. 88 p. https://fr.scribd.com/document/109453520/Agrodok-33-elevage-de-canards

[8] Mafouo, N.H., Teguia, A., Kana, J.R., Mube, H.K. and Diarra, M. (2011) Effet du niveau d'incorporation de la farine de manioc dans la ration sur les performances de croissance des poulets de chair. Livestock Research for Rural Development, 23, Article 76. http://www.lrrd.org/lrrd23/4/mafo23076.htm

[9] AOAC (1990) Association of Official Analytical Chemists. 15th Edition, Official Methods of Analysis, Washington DC.

[10] Van Soest, P.J., Robertson, J.B. and Lewis (1991) Methods for Dietary Fiber, Neutral Detergent Fiber and Non-Starch Polysaccharides in Relation to Animal Nutrition. Journal Dairy Sciences, 74, 3583-3597. https://doi.org/10.3168/jds.S0022-0302(91)78551-2 https://www.scirp.org/reference/ReferencesPapers.aspx?ReferenceID=1317997 
[11] Fadil, M., Abd Razak, A., Goh, Y.M., Mahdi, E. and Abdoreza, S.F. (2014) Palm Kernel Cake as a Potential Ingredient in Muscovy Ducks Diet. Italian Journal of Animal Science, 13, 30-35. https://doi.org/10.4081/ijas.2014.3035

[12] Meffeja, F., Dongmo, T., Fotsa, J., Tchakounte, J. and Ndube (2007) Effet du taux d'incorporation de la drêche des brasseries dans les rations alimentaires sur les performances des engraissements. Cahiers Agricultures, 12, 87-91.

[13] Panigrahi, S. and Powell, C.J. (1991) Effect of High Inclusion of Palm Kernel Meal in Broiler Chick Diets. Animal Feed Science and Technology, 34, 37-47. https://www.sciencedirect.com/science/article/pii/0377840194901902 https://doi.org/10.1016/0377-8401(94)90190-2

[14] Onifade and Babalunde (1998) Comparisons of the Utilization of Palm Kernel Meat, Brewers Dried Grains and Maize Offal by Broiler Chicks. British Poultry Sciences, 39, 245-250. https://www.redalyc.org/pdf/939/93944043011.pdf https://doi.org/10.1080/00071669889204

[15] Bello, K.M., Oyawoye E.O., Bogoro S.E. and Dass U.D. (2011) Performance of Broilers Fed Varying Levels of Palm Kernel Cake. International Journal of Poultry Science, 10, 290-294. https://scialert.net/fulltext/?doi=ijps.2011.290.294 https://doi.org/10.3923/ijps.2011.290.294

[16] Perez, J.F., Garnet, A.G. and Murillo, J.G. (2000) Effect of Different Levels of Palm Kernel Meal in Layers Diets. Poultry Sciences, 79, 77-79. https://www.researchgate.net/publication/313850523 https://doi.org/10.1093/ps/79.1.77

[17] Shakila, S., Sudhakara, P., Reddy, P.V.V.S., Reddy, R.J.V. and Ravi, A. (2012) Effect of Palm Kernel Meal on the Performance of Broilers. Tamilnadu Journal of Veterinary and Animal Sciences, 8, 227-234. https://pdfs.semanticscholar.org/b69d/091e2b93668

[18] Attia, Y.A., Qota, E.M.A., Aggoor, F.A.M. and Kies, A.K. (2003) Value for Rice Bran, Its Maximal Utilization and Its Upgrading by Phytase and Other Enzymes and Diet-Formulation Based on Available Amino Acids in the Diet for Broilers. Feedipedia: Animal Feed Resources Information System, 67, 157-166. https://www.researchgate.net/publication/254092453

[19] Osei, S.A. and Amo, J. (1986) Palm Kernel Cake as a Broiler Feed Ingredient. Poultry Science, 66, 1870-1873. https://doi.org/10.3382/ps.0661870 https://www.sciencedirect.com/science/article/pii/S0032579119564021

[20] Ezieshi, E.V. and Olomu, J.M. (2004) Comparative Performance of Broilers Chicken Feed Varying Levels of Palm Kernel Meal and Maize Offal. Pakistan Journal of Nutrition, 3, 254-257. https://www.feedipedia.org/node/13743 https://doi.org/10.3923/pjn.2004.254.257

[21] Soltan, M.A. (2009) Growth Performance, Immune Response and Carcass Traits of Broiler Chicks Fed on Graded Levels of Palm Kernel Cake without or with Enzyme Supplementation. Livestock Research for Rural Development, 21, Article 37. http://www.lrrd.org/lrrd21/3/solt21037.htm

[22] Yaakugh, I.D.I., Tegbe, T.S.B., Olorunju, S.A. and Aduku, A.O. (1994) Replacement of Brewers Dried Grains for Maize Performance of Pigs. Journal of Science Food and Agriculture, 66, 165-471. https://onlinelibrary.wiley.com/toc/10970010/66/4 https://doi.org/10.1002/jsfa.2740660407

[23] Okeudo, N.J., Eboh, K.V., Ndidi, V., Izugbekwe and Akanno, E.C. (2005) Growth Rate, Carcass Characteristics and Organoleptic Quality of Broiler Fed Graded Levels of Palm Kernel Cake. International Journal of Poultry Science, 4, 330-333. 
https://doi.org/10.3923/ijps.2005.330.333

[24] Orunmuyi, M., Bawa, G.S., Adeyinka, F.D., Daudu, O.M. and Adeyinka, I.A. (2006) Effects of Graded Levels of Palm Kernel Cake on Performance of Grower Rabbits. Pakistan Journal of Nutrition, 5, 71-74. https://www.feedipedia.org/node/6989 https://doi.org/10.3923/pjn.2006.71.74

[25] Fasina, O.E., Ologhobo, A.D., Adeniran, G.A., Ayoade, G.O., Adeyemi, O.A., Olayode, G. and Olubanjo, O.O. (2004) Toxicological Assessment of Vernonia amygdalina Leaf Meal in Nutrition of Starter Broiler Chicks. Nigeria Journal Animal Production, 31, 3-11. https://scialert.net/fulltext/?doi=ijps.2009.1206.1208

[26] Sarikhan, M., Shahryarh, A., Nazer-Adlk, Gholizadeh, B. and Behesht, B. (2009) Effects of Insoluble Fiber on Serum Biochemical Characteristics in Broiler. International Journal of Agriculture Biology, 11, 73-76.

http://www.scielo.br/scielo.php?script=sci arttext\&pid=S1516-635X2016000300451

[27] Moundras, C., Behr, S.R., Remesy, C. and Demigne, C. (1997) Interaction of Dietary Cholesterol and Sterols and Bile Acids Induced by Feeding Rats Guar Gum Are Due to Greater Triglycerides in the Regulation of Hepatic Low Density Lipoprotein Transport in Pool Size and Liver Bile Acid Secretion. Journal of Nutrition, 127, 1068-1076. https://link.springer.com/article/10.1007/s11745-000-542-X https://doi.org/10.1093/jn/127.6.1068 